\title{
Storage Stability and Sensory Acceptability of Low-Fat Spread Produced From Bambara Groundnut
}

\author{
Yusuf Amina Osizemeyele, Odion-Owase, Emmanuel And Suleiman Mohammed \\ Department of Food Technology, Auchi Polytechnic Auchi
}

\begin{abstract}
Standard methods were used to isolate and identify the microorganisms, and $\mathrm{pH}$, titrable acidity and sensory properties were determined. The microorganisms isolated from the low fat-food spread samples: Lactobacillus planetarium, Streptococcus lactis, Bacillus subtilis and Saccharomyces cerevisiae. The Bacterial counts ranged from $0.00 \times 10^{6} \mathrm{CFU} / \mathrm{g}-0.71 \times 10^{6}$ the fungal counts ranged from $1.33 \times 10^{6}-1.48 \times 10^{6} \mathrm{CFU} / \mathrm{g}$. The $\mathrm{pH}$ ranged $6.7-$ 7.1 units. There was no significant difference $(\mathrm{p} \leq 0.05)$ in the $\mathrm{pH}$ of the low-fat food spread samples. The titrable acidity ranged from $0.10-0.19$. There was no significant difference $(\mathrm{p} \leq 0.05)$ in the titrable acidity of the low-fat food spread samples. The sensory scores of the low-fat food spread, sample XY1 had the highest ratings and most preferred in taste and general acceptability. Sample XY6 was most preferred in texture and flavor, while sample XY3 had the least scores for all sensory attributes. There was no significant difference $(\mathrm{p} \leq 0.05)$ in color and textures for all the samples. However, there were significant difference $(p \leq 0.05)$ in taste and flavor of all the samples. The results showed that no pathogenic microorganisms were isolated within the 28 days storage period. Keywords: Bambara groundnut, storage stability, low-fat food spread, acceptability.
\end{abstract}

DOI: $10.7176 / \mathrm{JNSR} / 12-20-02$

Publication date:October $31^{\text {st }} 2021$

\section{Introduction}

In recent years, legume has been successfully converted into low-cost edible products such as spread (Mangels et al., 2001). The common ingredients used for producing seed spread are pumpkin, sunflower and sesame seed and soya beans. Seed spread have grown to be a popular product in the market, being an alternative to margarine (Steveson, et al., 2017).

Spreads are usually made with heat-treated seeds and nuts. Apart from the traditional spread such as butter and margarine, plants spread are commonly produced from peanut and legumes. Low-fat food spread is a nutritious food product with most of the essential amino acids, carbohydrates, fats, minerals and vitamins (Table1). The presence of these nutrients in low-fat food spread promote the growth of pathogens. The nutrients in these Low-fat food spreads are essential for microbial growth with glucose serving as carbon and energy source (Jimenez-Matinez et al., 2003). The survival of food borne pathogens in low-fat food spread are therefore, of importance. Recently, there has been increased concern regarding the presence of pathogens in food industries. The common sources of these contamination are workers and equipment (Simonne et al., 2010). As such, contaminants may persist through manufacturing, distribution, storage and eventually reach consumers unabated at consumption (De Vries, 1996). Typically, pathogenic microbes and the toxins they produce are the major food safety hazards associated with food products (Bachrouri et al., 2006) .

Diverse storage temperatures and times have been implicated to be responsible for changes in quality characteristics of food products (Obi et al., 2010; Osman and Razig 2010). Improper storage of food can lead to spoilage within a short period of time (Mataragas et al., 2011). The storage conditions under which food such food spreads are stored are important.

This research aimed at studying storability, the changes in $\mathrm{pH}$ and titratable acidity, microbial quality, of low-fat food spread produced from Bambara groundnut and supplemented with peanut for 28 days storage period.

\section{MATERIALS AND METHODS}

Materials:The Bambara groundnut, (virginal subterranean) seeds were obtained from local farmers In Odu Ogbeyag, Dekina Local Government area of Kogi East, Kogi State, North-Central Nigeria. The salt and ascorbic acid were obtained from Hallmark supermarket, Sapele Road, Benin City, Edo State.

Method:The Bambara groundnut seed $(500 \mathrm{~g})$ were roasted in an oven at $120^{\circ} \mathrm{C}$ for 1 hour. The roasted Bambara groundnut was cooled and blanched at $100^{\circ} \mathrm{C}$ for 8 minutes, dehulled and dried back to moisture contents of $12 \%$ at temperature of $60^{\circ} \mathrm{C}$ for 1 Hour in an oven (Jenway model). Milled into powder in stainless steel blender (Waring laboratory model HGBTWG4 USA) and homogenized with a laboratory Silverson homogenizer while additives, salt, dextrose, ascorbic acid, yeast, gelatin and hydrogenated fat were all added, at varying levels of $6.5 \mathrm{~g}, 22 \mathrm{~g}, 2 \mathrm{~g}, 1 \mathrm{~g}, 44 \mathrm{~g}$ and $20 \mathrm{~g}$ respectively 


\section{METHOD}

Microbial Analysis

Standard microbiological methods were used. The microorganisms isolated were also enumerated, characterized and confirmed using standard bacteriological and mycological methods as described by Cheesebruog (2014). Analysis were carried out for a period of four (4) weeks.

Determination of pH and Titrable Acidity (TTA) Using pH Meter (3510). TTA was measured by the samples against $0.1 \mathrm{NaOH}$ and expressed as percentage lactic acid. Phenolphthalein was used as an indicator (Amerine et al., 1967).

Consumer's Acceptability of Low-fat food spread.

Consumer's acceptability was carried out on the freshly prepared low-fat food spread samples. The sensory attributes of low-fat spread samples were evaluated using 9-point hedonic scale where 1 represents dislike extremely and 9 to like extremely. Ten (10) regular consumers of food spread were recruited from Auchi Polytechnic Community, Auchi.

\section{RESULTS}

\section{TABLE 1: Isolated Microorganisms}

\begin{tabular}{lllll}
\hline XY1 & $\underline{\text { Streptococcus }}$ & $\underline{\text { lactis }}$ & $\underline{\text { Saccharomyces }}$ & $\underline{\text { Cerevisiae }}$ \\
XY2 & $\underline{\text { lactobacillus }}$ & $\underline{\text { lactobacium }}$ & $\underline{\text { saccharomyces }}$ & $\underline{\text { cerevisiae }}$ \\
XY3 & $\underline{\text { Streptococcus }}$ & $\underline{\text { lactis }}$ & $\underline{\text { saccharomyces }}$ & $\underline{\text { cerevisiae }}$ \\
XY4 & $\underline{\text { Streptococcus }}$ & $\underline{\text { lactis }}$ & $\underline{\text { saccharomyces }}$ & $\underline{\underline{\text { cerevisiae }}}$ \\
XY5 & $\underline{\text { Bacillus }}$ & $\underline{\text { subtilis }}$ & $\underline{\text { sacharomyces }}$ & $\underline{\underline{\text { cerevisiae }}}$ \\
XY6 & $\underline{\text { pactobacillus }}$ & $\underline{\text { sacharomyces }}$ & $\underline{\text { cerevisiae }}$ \\
XY7 & & $\underline{\text { cerevisiae }}$
\end{tabular}

Where: XYI: 1:9 Peanut/BGN; XY2: 2:8 Peanut/BGN; XY3: 3:7 Peanut/BGN; XY4: 4:6 Peanut/BGN; XY5:5:5 Peanut/BGN.

XY6: 100\% BGN and XY7 100\% Peanut

\section{RESULTS}

TABLE 2: Bacterial counts of samples (CFU/g)

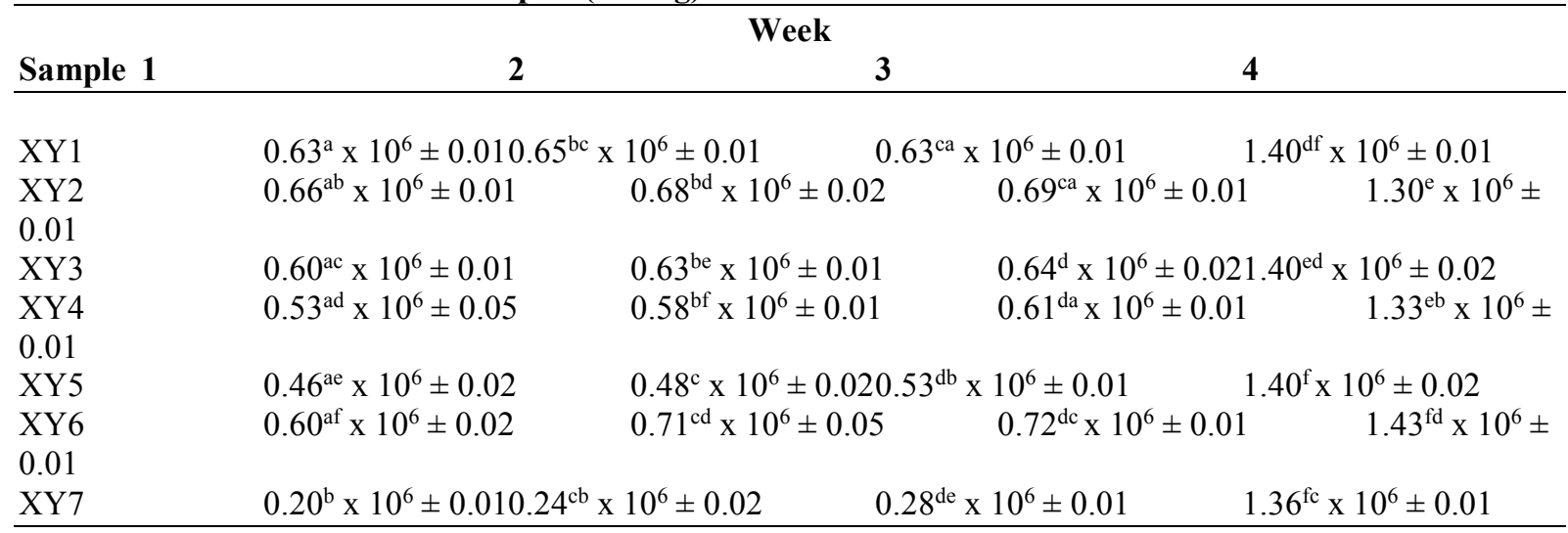

Means with the same superscripts down the column are not significantly different $(\mathrm{P}>0.05)$

Where: XYI: 1:9 Peanut/BGN; XY2: 2:8 Peanut/BGN; XY3: 3:7 Peanut/BGN; XY4: 4:6 Peanut/BGN; XY5:5:5 Peanut/BGN; X

$$
\text { Y6: } 100 \% \text { BGN and XY7 100\% Peanut }
$$


TABLE 3: Fungal counts of samples (CFU/g)

\begin{tabular}{|c|c|c|c|c|}
\hline & & 2 & 2 & 4 \\
\hline $\mathrm{XY1}$ & - & - & - & $1.40^{\mathrm{a}} \times 10^{6} \pm$ \\
\hline \multicolumn{5}{|l|}{0.01} \\
\hline XY2 & - & - & - & $1.48^{\mathrm{ab}} \times 10^{6} \pm$ \\
\hline \multicolumn{5}{|l|}{0.02} \\
\hline XY3 & - & - & - & $1.43^{\mathrm{ac}} \times 10^{6} \pm$ \\
\hline $\begin{array}{l}0.01 \\
\text { XY4 }\end{array}$ & - & - & - & $1.33^{\mathrm{ad}} \times 10^{6} \pm$ \\
\hline \multicolumn{5}{|l|}{0.02} \\
\hline XY5 & - & - & - & $1.40^{\mathrm{b}} \times 10^{6} \pm$ \\
\hline \multicolumn{5}{|l|}{0.01} \\
\hline XY6 & - & - & - & $1.36^{\mathrm{bd}} \times 10^{6} \pm$ \\
\hline \multicolumn{5}{|l|}{0.05} \\
\hline XY7 & - & - & - & $1.38^{\mathrm{bc}} \times 10^{6} \pm$ \\
\hline 0.02 & & & & \\
\hline
\end{tabular}

Means with the same superscripts down the column are not significantly different $(\mathrm{P}>0.05)$

Where: XYI: 1:9 Peanut/BGN; XY2: 2:8 Peanut/BGN; XY3: 3:7 Peanut/BGN; XY4: 4:6 Peanut/BGN; XY5:5:5 Peanut/BGN;

XY6: $100 \%$ BGN and XY7 100\% Peanut

TABLE 4: PH of samples

\begin{tabular}{lllll}
\hline Sample & $\mathbf{1}$ & $\mathbf{2}$ & Week & $\mathbf{3}$ \\
\hline XY1 & $7.20^{\mathrm{a}} \pm 0.05$ & $7.20^{\mathrm{ad}} \pm 0.02$ & $7.10^{\mathrm{ab}} \pm 0.02$ & $\mathbf{4}$ \\
XY2 & $7.10^{\mathrm{ab}} \pm 0.01$ & $7.10^{\mathrm{c}} \pm 0.01$ & $6.98^{\mathrm{de}} \pm 0.03$ & $6.73^{\mathrm{fb}} \pm 0.05$ \\
XY3 & $7.26^{\mathrm{ac}} \pm 0.02$ & $7.28^{\mathrm{cd}} \pm 0.02$ & $7.12^{\mathrm{e}} \pm 0.02$ & $6.76^{\mathrm{fd}} \pm 0.02$ \\
XY4 & $7.15^{\mathrm{ad}} \pm 0.05$ & $7.17^{\mathrm{ca}} \pm 0.05$ & $7.01^{\mathrm{ef}} \pm 0.01$ & $6.73^{\mathrm{fb}} \pm 0.05$ \\
XY5 & $7.23^{\mathrm{b}} \pm 0.02$ & $7.26^{\mathrm{ce}} \pm 0.01$ & $7.03^{\mathrm{e}} \pm 0.02$ & $6.68^{\mathrm{g}} \pm 0.05$ \\
XY6 & $7.32^{\mathrm{bc}} \pm 0.01$ & $7.39^{\mathrm{cf}} \pm 0.02$ & $7.12^{\mathrm{e}} \pm 0.01$ & $6.71^{\mathrm{gb}} \pm 0.01$ \\
XY7 & $7.10^{\mathrm{ab}} \pm 0.02$ & $7.24^{\mathrm{d}} \pm 0.05$ & $7.10^{\mathrm{db}} \pm 0.02$ & $6.75^{\mathrm{gc}} \pm 0.01$ \\
\hline
\end{tabular}

Means with the same superscripts down the column are not significantly different $(\mathrm{P}>0.05)$

Where: XYI: 1:9 Peanut/BGN; XY2: 2:8 Peanut/BGN; XY3: 3:7 Peanut/BGN; XY4: 4:6 Peanut/BGN; XY5:5:5 Peanut/BGN;

XY6: $100 \%$ BGN and XY7 100\% Peanut

TABLE 5: Titratable acidity of samples

\begin{tabular}{|c|c|c|c|c|c|c|}
\hline \multicolumn{7}{|c|}{ Week } \\
\hline Sample & 1 & 2 & & 3 & & \\
\hline$\overline{X Y 1}$ & $0.13^{\mathrm{a}} \pm 0.02$ & & $0.13^{b} \pm 0.05$ & & $0.15^{\mathrm{cb}} \pm 0.01$ & $0.19^{\mathrm{gb}} \pm 0.02$ \\
\hline XY2 & $0.11^{\mathrm{ab}} \pm 0.01$ & & $0.12^{b c} \pm 0.01$ & & $0.16^{\mathrm{cd}} \pm 0.02$ & $0.17^{\mathrm{gh}} \pm 0.01$ \\
\hline XY3 & $0.14^{\mathrm{ad}} \pm 0.01$ & & $0.13^{b} \pm 0.01$ & & $0.15^{\mathrm{cb}} \pm 0.03$ & $0.16^{\mathrm{e}} \pm 0.02$ \\
\hline XY4 & $0.10^{\mathrm{ac}} \pm 0.02$ & & $0.11^{\text {bd }} \pm 0.05$ & & $0.17^{\mathrm{cf}} \pm 0.01$ & $0.18^{\mathrm{ef}} \pm 0.01$ \\
\hline XY5 & $0.14^{\mathrm{ad}} \pm 0.01$ & & $0.15^{\mathrm{bf}} \pm 0.02$ & & $0.16^{\mathrm{cd}} \pm 0.05$ & $0.18^{\mathrm{ef}} \pm 0.01$ \\
\hline XY6 & $0.15^{\mathrm{ae}} \pm 0.02$ & & $0.16^{c} \pm 0.02$ & & $0.18^{\mathrm{g}} \pm 0.01$ & $0.19^{\mathrm{gb}} \pm 0.02$ \\
\hline XY7 & $0.14^{\mathrm{ad}} \pm 0.03$ & & $0.15^{\mathrm{bf}} \pm 0.01$ & & $0.17^{\mathrm{cf}} \pm 0.05$ & $0.18^{\mathrm{ef}} \pm 0.01$ \\
\hline
\end{tabular}

Means with the same superscripts down the column are not significantly different $(\mathrm{P}>0.05)$

Where: XYI: 1:9 Peanut/BGN; XY2: 2:8 Peanut/BGN; XY3: 3:7 Peanut/BGN; XY4: 4:6 Peanut/BGN; XY5:5:5 Peanut/BGN; 
Table 6: Sensory Acceptability of low-fat food spread samples

\begin{tabular}{|c|c|c|c|c|c|}
\hline & COLOUR & TEXTURE & TASTE & FLAVOUR & G/ACCEPTABILITY \\
\hline $\mathrm{XY} 1$ & $8.50^{\mathrm{d}} \pm 0.33$ & $8.40^{\mathrm{a}} \pm 0.54$ & $8.80^{\mathrm{a}} \pm 0.42$ & $8.60^{\mathrm{a}} \pm 0.84$ & $8.70^{\mathrm{a}} \pm 0.67$ \\
\hline $\mathrm{XY} 2$ & $7.90^{\mathrm{a}} \pm 0.56$ & $8.10^{\mathrm{a}} \pm 0.87$ & $8.30^{\mathrm{ab}} \pm 0.94$ & $8.20^{\mathrm{a}} \pm 0.78$ & $8.30^{\mathrm{abc}} \pm 0.82$ \\
\hline $\mathrm{XY} 3$ & $7.90^{\mathrm{a}} \pm 0.87$ & $7.90^{\mathrm{a}} \pm 0.56$ & $7.70^{b} \pm 0.82$ & $7.80^{\mathrm{ab}} \pm 0.78$ & $7.60^{\mathrm{c}} \pm 0.69$ \\
\hline $\mathrm{XY} 4$ & 7. $80^{\mathrm{a}} \pm 0.78$ & $7.70^{\mathrm{a}} \pm 0.82$ & $8.00^{\mathrm{ab}} \pm 0.94$ & $7.90^{\mathrm{ab}} \pm 0.73$ & $7.90^{\mathrm{abc}} \pm 0.87$ \\
\hline $\mathrm{XY} 5$ & $7.90^{\mathrm{a}} \pm 0.73$ & $8.00^{\mathrm{a}} \pm 0.67$ & $7.80^{b} \pm 0.92$ & $6.90^{\mathrm{b}} \pm 2.56$ & $7.700^{\mathrm{bc}} \pm 0.82$ \\
\hline XY6 & $8.40^{\mathrm{a}} \pm 0.69$ & $8.50^{\mathrm{a}} \pm 0.85$ & 8. $40^{\mathrm{ab}} \pm 0.11$ & $8.90^{\mathrm{a}} \pm 7.00$ & $8.30^{\mathrm{abc}} \pm 0.95$ \\
\hline XY7 & $8.20^{\mathrm{a}} \pm 0.79$ & $7.90^{\mathrm{a}} \pm 0.99$ & $8.00^{\mathrm{ab}} \pm 1.05$ & $7.60^{\mathrm{ab}} \pm 0.69$ & $8.50^{\mathrm{ab}} \pm 0.85$ \\
\hline
\end{tabular}

Where: XYI: 1:9 Peanut/BGN; XY2: 2:8 Peanut/BGN; XY3: 3:7 Peanut/BGN; XY4: 4:6 Peanut/BGN; XY5:5:5 Peanut/BGN; XY6: 100\% BGN and XY7 100\% Peanut

\section{Discussion.}

Microbial quality, $\mathrm{pH}$ and TTA of low-fat food spread stored over a period of 28 days were evaluated. Microorganisms, Lactobacillus plantarum, Streptococcus lactis, Bacillus subtilis and Saccharomyces cerevisiae were isolated from the samples. These isolated microorganisms were not pathogenic, however, have health benefits to humans. These microorganisms have been found to be responsible for fermentation of most legumes and cereals (Tucker, 2003). The bacterial and fungi counts were not significant. The bacterial and fungi counts were very low. There wasn't a significant difference $(\mathrm{P} \leq 0.05)$ in the bacterial and fungi counts of the samples after four weeks. The bacteria counts ranged from $0.02 \times 10^{6} \mathrm{CFU} / \mathrm{g}$ to $1.43 \times 10^{6} \mathrm{CFU} / \mathrm{g}$, while the fungi count ranged from $1.33 \times 10^{6} \mathrm{CFU} / \mathrm{g}$ to $1.48 \times 10^{6} \mathrm{CFU} / \mathrm{g}$. The results of the $\mathrm{pH}$ revealed the values which ranged from 6.68-7.10. This may be due to the production of organic acids such as lactic acid which has been found to reduce the $\mathrm{pH}$ value. The total titrable acidity (TTA) increased throughout the period of storage. The increase in titrable acidity may be due to the increase in activities of microorganisms resulting in the production of organic acids from available nutrients. However, shelf life of the low-fat food spread samples was stable and no predication of spoilage for the period considered.

\section{Consumer's Acceptability of low-fat food spread}

The addition of peanuts seems not to influence aroma, taste and consistency since there was no significant difference in these parameters $(\mathrm{P} \leq 0.05)$, (Table 6). However, peanut spread showed slightly higher rating (approx. 8.40) for color compared to other samples. Previous findings similarly did not observe much variation in taste of roasted peanuts and Bambara groundnut, (Okafor et al., 2014; Omije et al., 2018).

Means values followed by superscript letters were not significantly different. Where: 90:10, 80:20, 70:30, $60: 40,50: 50,100: 0$, and 100:0 were BGN and peanuts ratios respectively. The color ranged (7.90-8.40) acceptability of low-fat food spread of all the samples were not significantly different. Texture range (7.70-8.50) mean scores were not significantly different. The taste range (7.70-8.80), sample XY6 and XY7 were not significantly different. Roasted Bambara groundnut smells and taste like roasted peanuts (Yusuf et al., 2008) but has not be implicated in allergies like peanut and dairy (Philip 2014). Flavor of sample range (6.90-8.89) The samples XY6 and XY7 were not significantly different, this could be due the facts both matrixes used were roasted. Nevertheless, the ratings in color, taste, texture and flavor of all the samples may have been developed as result of roasting which significantly improved organoleptic qualities of low-fat food spread. Controlled roasting of nuts and grains result in formation of desired roasted aroma in food which may been designated as nutty, burnt and coffee-like, due to the formation pyrazine compounds that have also been implicated in extent of brown color formation in food products (Powrie and Nankai, 1981; Okafor et al., 2014).

The control sample XY7 which scores were comparable to that of sample XY6. Where 100\% peanuts which serve as control and XY6 100\% BGN the test sample in all the parameter evaluated by the Judges. The spread made from $50 \%$ and $50 \%$ substitution was also ranked next to the test sample. The increase in the substitution of Bambara groundnut with the decrease in peanut resulted in the increased acceptability of the low-fat food spread as indicated in the ratings of the sample with 8:2 ratio. The low-fat food spread substituted in ratio 9:1 (Bambara and peanut) was reported to have crumbly texture due to decrease in substitution of peanuts. However, the substitution produced organoleptically acceptable low-fat food spread. Bambara groundnut is a valuable food grain that could be considered a suitable matrix for development and production of acceptable low-fat food spread with good quality storage stability. 


\section{REFERENCES}

Chesbrough, M. (2014) District Laboratory Practice in Tropical. Low price $2^{\text {nd }}$ Edition update. Cambridge University Press, United Kingdom pp 492.

Bachrouri, M., Quinto, E. and Mora, M. 2006. Kinetic parameters of Escherichia coli O157: H7 survival during fermentation of milk and refrigeration of home-made yoghurt. International Dairy Journal, 16 (5): 474-481.

De Vries, J. 1996. Food Safety and Toxicity. CRC press

Devereux, H., Jones, G., McCormack, L. and Hunter, W. 2003. Consumer acceptability of low- fat foods containing inulin and oligofructose. Journal of Food Science, 68 (5): 1850-1854.

Jiménez_Martínez, C., Hernández _Sánchez, H. and Dávila _Ortiz, G. 2003a. Production of a yogurt_like product from Lupinus campestris seeds. Journal of the Science of Food and Agriculture, 83 (6): 515-522.

Mataragas, M., Dimitriou, V., Skandamis, P. and Drosinos, E. 2011.Quantifying the spoilage and shelf-life of yoghurt with fruits. Food Microbiology, 28 (3): 611-616.

Nielsen, S.S (2002), Introduction to the chemical Analysis of Foods, $4^{\text {th }}$ Edition. Boston: Jones and Bartlet Publishers, New Delhi, India. 81-2006.

Obi, T., Henshaw, F. and Atanda, O. 2010. Quality evaluation of plain-stirred probiotic yoghurt produced from skim and whole milk powder during refrigerated storage. Electronic Journal of Environmental, Agricultural and Food Chemistry, 9 (7): 1203-1213.

Okafor JNC; Ani J.C, Okafor G.I 2014. Effect of processing methods on qualities of BBAN Voandzela subterranean (L/Thouars) Flour and their Acceptability in Extruded Shacks American journal of Technology 9 (7) $350-359$.

Omijie, A B, Yusuf A O, 2018. Proximate Composition and Consumer's Acceptability of low-fat from Bambara groundnut Project work, Department of Food Technology, Auchi, Polytechnic, Auchi, Nigeria.

Powrie, W.D. and Nakai, 1981. Processing Effects on Protein Systems. In: Utilization of Protein of Resources. Tucker, S.C (2003). Floral Development in Legumes. Journal of plant Physiology 131.911-926.

Simonne, A., Brecht, J., Sargent, S., Ritenour, M. and Schneider, K. R. 2010.Good Worker Health and Hygiene Practices: Training Manual for Produce Handlers.

Stevenson to, D. G., ELLER, F. J., Wang, L.; Jane, J.; Wang, T.; and Ingett, G.E. (2007). Oil and Tocopherol Content and Composition of Pumpkin Seed in 12 Cultivars. Journal of Agricultural food Chemistry 55: 4005- $B$.

Yusuf A.O; Shode F.; Ijabadeniyi O.A 2017 Quality and Storage stability of yoghurt produced from pigeon pea milk supplemented with Propionibacterium freudenreichii MSc thesis Durban University of Technology South African.

\section{ACKNOWLEDGEMENT}

The Scholars are indeed grateful to TETfund for the opportunity afforded them to contribute to knowledge and nation building in terms of food innovation. 